\title{
Evaluating the use of loop-mediated isothermal amplification (LAMP) method for detection of Mycobacterium tuberculosis in Indonesian clinical isolates
}

\author{
Vivi Lisdawati, ${ }^{1}$ Tomohiro Oshibe, ${ }^{2}$ Hidetaka Tsuji, ${ }^{2}$ Tjahjani M. Sudiro, ${ }^{3}$ Myrna Adianti, ${ }^{4}$ Triyani Sukarso, ${ }^{1}$ \\ Holy Arief, ${ }^{1}$ Hak Hotta, ${ }^{4}$ Pratiwi Sudarmono ${ }^{3}$ \\ ${ }^{1}$ Center for Biomedical and Basic Technology of Health, National Institute of Health Research and Development, Ministry of Health, \\ Jakarta, Indonesia \\ ${ }^{2}$ Hyogo Perfectural Institute of Public Health and Consumer Science, Public Health Science Research, Japan \\ ${ }^{3}$ Department of Microbiology, Faculty of Medicine, Universitas Indonesia, Jakarta, Indonesia \\ ${ }^{4}$ Department of Microbiology, Kobe University Graduate School of Medicine, Japan
}

\begin{abstract}
Abstrak
Latar belakang: Metode loop-mediated isothermal amplification (LAMP) merupakan metode sederhana yang dapat mengamplifikasi DNA/RNA menggunakan empat sampai dengan enam primer dalam bentuk "pasangan" dari sekuens conserved gen. Penelitian ini bertujuan untuk mengoptimasi LAMP dalam menegakkan diagnosis kasus TB di Indonesia.

Metode: Setelah uji optimasi, metode LAMP kemudian diujikan pada 122 DNA Mycobacterium tuberculosis (Mtb) sampel tersimpan, yang merupakan spesimen sputum pasien TB dengan BTA positifyang dikumpulkan dari 13 provinsi di Indonesia pada tahun 2008 untuk studi genotipe dan merupakan koleksi Pusat Biomedis dan Teknologi Dasar Kesehatan (PBTDK), Balitbangkes. Uji optimasi meliputi uji sensitifitas dan uji spesifisitas sejumlah pasangan primer LAMP terhadap larutan serial DNA Mtb H37Rv dan 12 spesies Mycobacteria. Uji LAMP dilakukan menggunakan tiga jenis instrumen yaitu LAMP turbidemeter, pelat pemanas dan penangas air. Hasil pengujian beberapa pasang primer dan instrument ini kemudian diterapkan untuk uji LAMP pada isolat spesimen klinik Indonesia, yaitu menggunakan pasangan primer dari gen gyrB, Hasil amplifikasi dideteksi dengan lampu UV.

Hasil: Uji sensitivitas menunjukkan bahwa pasangan primer gen I6S rRNA dan gyrB memberikan hasil terbaik yaitu mampu mendeteksi 10.0 fg - 1.0 pg genomik DNA Mtb H37Rv. Uji spesifisitas menunjukkan bahwa pasangan primer gen gyrB merupakan pasangan primer paling spesifik. Hasil pengujian pasangan primer gyrB pada isolat klinis Indonesia didapatkan positivity rate $94,2 \%(114 / 121)$.
\end{abstract}

Kesimpulan: Metode LAMP berpotensi untuk digunakan dalam diagnosis kasus TB di Indonesia. (Med J Indones. 2012;21:188-95)

\begin{abstract}
Background: Loop-mediated isothermal amplification (LAMP) is a method already claimed as a simple technique to amplify DNA/ RNA using four to six primers as "a set" from conserved sequence of target gene. In this study we optimize the use of LAMP for detection of Mycobacterium tuberculosis in clinical isolates from Indonesia.

Methods: Procedures to perform LAMP were optimized, then the method was applied to 122 archieved samples of DNA's Mtb from clinical TB patients with Acid Fast Bacilli (AFB) smears positive. The samples were obtained in 2008 from 13 provinces in Indonesia for genotyping study, which then become collections of Center for Biomedical and Basic Technology of Health (CBBTH), NIHRD Indonesia. The optimization tests include sensitivity and specificity tests of several sets primers, which were evaluated using 10-fold serially diluted DNA of Mtb H37Rv and 12 species of Mycobacteria. Three equipments consisted of LAMP turbidimeter, heating block and water bath were compared for its ability in DNA amplification. Detection of $M$. tuberculosis from clinical isolates used set primers specific for gyrB gene, amplicon was detected with UV fluorescence system.

Results: The results showed that the highest sensitivity was obtained using the set primers specific for 16S rRNA and gyrB which could detect $10.0 \mathrm{fg}$ to $1.0 \mathrm{pg}$ genomic DNA of Mtb H37Rv. The set primers specific for gyrB gene was the most specific primers. Application of LAMP using gyrB set primers on Indonesian clinical isolates showed 94.2\% (114/121) positivity rate.
\end{abstract}

Conclusion: LAMP method is potentially used in TB diagnosis in Indonesia. (Med J Indones. 2012;21:188-95)

Keywords: Loop-mediated isothermal amplification, rim gene, $16 \mathrm{~S}$ rRNA gene, gyrB gene, Mycobacterium tuberculosis

The microscopic examination of sputum is the only widely available tool in most developing countries for diagnosing tuberculosis (TB), as it is low cost and easily available. Lack of standardized procedure and trained microscopist on reading acid-fast bacilli (AFB) sputum smear appear to be the major drawbacks to case finding in countries with limited sources. ${ }^{1}$ AFB sputum smears of clinical specimens require at least $10^{4}$ bacilli per milliliter for detection from concentrated specimens and is relatively insensitive in the presence of HIV co-infection. ${ }^{2} \mathrm{New}$ technologies with higher sensitivity and specificity 
are urgently needed to confirm the clinical diagnosis and furthermore interrupt TB transmission.

Loop-mediated isothermal amplification (LAMP) technology is modified technique from Nucleic Acid Amplification Assays (NAAs) which can be used for direct detection of $M t b$ in clinical specimens. This method is based on the Polymerase Chain Reaction (PCR) principle and can reduce the weaknesses of several previous methods of NAAs, such as nucleic acid sequence-based amplification (NASBA), self-sustained sequence replication (3SR) and strand displacement amplification (SDA). ${ }^{3}$ The amplification products are stem-loop DNA structures with several inverted repeats of the target and cauliflower-like structures with multiple loops, yielding amounts greater than 500 $\mu \mathrm{g} / \mathrm{mL}$ of DNA. ${ }^{4}$

LAMP method relies on autocycling strand displacement DNA synthesis by a Bst DNA polymerase. The amplification of DNA is directly correlated with the production of precipitation as the reaction's result, leading to an increase of the solution turbidity. LAMP reaction can be monitored in real-time by measuring the solution turbidity in an inexpensive photometer or by daylight visualization. .,6 $^{5,6}$ Characterization of LAMP method is carried out using at least 4 different primers which are specifically designed to recognize 6 or more distinct regions, on the target DNA. The primers used are inner, backward and also loop primers to reduce the duration of amplification. The amplification occurs at a constant temperature using strand displacement reaction, therefore it can replace the need of thermocycler machine like usually used in conventional PCR by simple incubator or block heater. Hence, the reaction is conducted at the optimal temperature for enzyme function, and the inhibition of the reaction that occurs at later stages of amplification, a typical problem with PCR, is less likely to take place..$^{7-9}$ There is no time loss for thermal change due to its isothermal reaction and it is limited only by the amount of deoxynucleotide triphosphates and primers of the gene. The higher amplification efficiency of the RTLAMP method enables simple visual observation of amplification with naked eyes under UV lamp in the presence of an intercalating dye, such as SYBR Green I or ethidium bromide. ${ }^{10}$ Thus, this method could be a potential valuable tool for the rapid diagnosis of infectious diseases in either commercial or hospital laboratories. A feasibility study using LAMP for detection of $M t b$ from culture-positive sputum, was carried out in Microscopy Centers in Lima, Peru, Dhaka, Bangladesh and Mbeya showed good sensitivity. ${ }^{11}$
Optimization tests of LAMP-TB assay are important to analyze whether this technology can be recommended for diagnosis TB in limited sources areas, such as in Indonesia. The first optimization was the sensitivity study of two commercialized DNA extraction kits (Qiagen and Amplicor) and DNA amplification LAMP kit $^{12,13}$ (Eiken Chemical Co. Ltd.) using set primers specific for 16S rRNA gene by Pandey et al. ${ }^{14}$

The second optimization was to verify the sensitivity of "four sets" LAMP primers for TB assay which had been published elsewhere; consisted of one set primers specific for rim $\mathrm{M}$ gene ${ }^{15}$ one set for $g y r \mathrm{~B}$ gene ${ }^{5}$ and two sets primers specific for $16 \mathrm{~S} r$ RNA gene by Pandey et al and Yamaguchi et al. ${ }^{14,16}$ The specificity of the "sets primers" was evaluated against twelve DNA's Mycobacteria sp., The sensitivity of some simple equipments for LAMPTB nucleic amplification and system detection were also evaluated. After the optimization tests, the reliability test of the method was continued using set primers specific for $g y r B$ gene $^{5}$ to diagnose 122 archived MTB DNA from Indonesian TB patients.

\section{METHODS}

\section{Optimization of LAMP method}

\section{DNA preparation: efficiency of extraction kit and loopamp DNA amplification kit}

This study used DNA's extract A and B in 10-fold serial dilutions of M. tuberculosis H37Rv culture fluid, which was prepared using two different commercial kits from QIAamp DNA mini kit (Qiagen, Germany) and Amplicor DNA mini kit (Roche, AMPLICOR) respectively. ${ }^{12,17}$ The initial processing of specimens was performed under biosafety level 3 containment facilities. Extraction of the Mtb H37Rv was performed following the procedure described in the kits' manual.

A set of six primers specific for 16S rRNA gene was used in this study. ${ }^{14}$

Amplification reaction: The reaction was carried out in a $25 \mu \mathrm{L}$ total reaction mixture with Loopamp DNA amplification kit (Eiken Chemical Co Ltd.) containing 30 pmol of each inner primers FIP and BIP, 5 pmol of F3 and B3 outers primers, 20 pmol of each F and B loop primers, $12.5 \mu \mathrm{L}$ of $2 \mathrm{x}$ reaction mix [40 mM Tris-HCl pH8.8; $20 \mathrm{mM} \mathrm{KCl} ; 16 \mathrm{mM} \mathrm{MgSO} 4 ; 20$ mM (NH4)2SO4; 0.2\% Tween20; 1.6 M Betaine; 2.8 $\mathrm{mM}$ dNTPs], $1.0 \mu \mathrm{l}$ of Bst DNA polymerase, amount of DW and $2.0 \mu \mathrm{L}$ of template DNA. The mixture was incubated at $64^{\circ} \mathrm{C}$ for $60 \mathrm{~min}$ in LAMP real-time 
turbidimeter (LA-320C; Teramecs) and then heated at $80^{\circ} \mathrm{C}$ for $2 \mathrm{~min}$ to inactivate the amplification.

\section{Sensitivity of LAMP primers sets for rapid detection of Mtb}

DNA's extract A was used throughout this study. There were "four sets" of LAM-TB primers used for rapid detection of $M t b$ assays (Table 1). Set primers I, by Iwamoto et al: $:^{10}$ amplification at $63^{\circ} \mathrm{C}$ for 60 min, inactivation at $80^{\circ} \mathrm{C}$ for $2 \mathrm{~min}$. Set primers II, by
Yamaguchi et $\mathrm{al}^{16}$ amplification at $65^{\circ} \mathrm{C}$ for $60 \mathrm{~min}$ and inactivation at $80^{\circ} \mathrm{C}$ for $2 \mathrm{~min}$. Set primers III, by Pandey et a $\mathrm{a}^{12}$ amplification at $64^{\circ} \mathrm{C}$ for $60 \mathrm{~min}$ and inactivation at $80^{\circ} \mathrm{C}$ for $2 \mathrm{~min}$. Set primers IV, by Zhu et $\mathrm{al}^{15}$ amplification at $65^{\circ} \mathrm{C}$ for $60 \mathrm{~min}$ and inactivation at $80^{\circ} \mathrm{C}$ for $2 \mathrm{~min}$.

Amplification reaction: The Loopamp DNAamplification kit (Eiken Chemical Co Ltd.) was amplified in a $25-\mu \mathrm{L}$ reaction mixture containing the set of primers on gene targets according to previous studies, ${ }^{5,12,15,16} 2 \mathrm{x}$ Reaction Mix, 1.0 $\mu \mathrm{L}$ of the Bst DNA

Table 1. The four sets of LAMP primers used for Rapid Detection of Mtb assays

\begin{tabular}{|c|c|c|c|c|}
\hline $\begin{array}{c}\text { Primer } \\
\text { Set }\end{array}$ & Primer & Sequence & $\begin{array}{l}\text { Gene } \\
\text { Target }\end{array}$ & $\begin{array}{l}\text { Conc. } \\
\text { Used }\end{array}$ \\
\hline \multirow[t]{6}{*}{ I } & F3 & GCGATATCTGGTGGTCTG & gyrB & 5 pmol \\
\hline & B3 & CCGTGGTTTCGAAAACAGC & gyrB & $5 \mathrm{pmol}$ \\
\hline & FIP & AGACCACTCGTACCCGTCGCCGGTGGTTAACGCGCTAT & gyrB & 40 pmol \\
\hline & BIP & ATGAGAAGTCGGAACCCCTGGGACCGTTGACCCCGTCTTC & gyrB & 40 pmol \\
\hline & Loop F & AACTAGAGCTGAAGCTCGG & gyrB & $20 \mathrm{pmol}$ \\
\hline & Loop B & CCTCAAGCAAGGGGCG & gyrB & 20 pmol \\
\hline \multirow[t]{6}{*}{ II } & F3 & GATACTCGAGTGGCGAACG & 16S rRNA & $10 \mathrm{pmol}$ \\
\hline & B3 & TACCCGTCGTCGCCTTG & 16S rRNA & $10 \mathrm{pmol}$ \\
\hline & FIP & ATCCCGTGGTCCTATCCGTCTGCCCTGCACTTCGG & 16S rRNA & 40 pmol \\
\hline & $\mathrm{BIP}$ & GCGCTTTAGCGGTGTGGCCGTCACCCCACCAACA & 16S rRNA & $40 \mathrm{pmol}$ \\
\hline & Loop F & AGACCCAGTTTC CCAGG & 16S rRNA & $40 \mathrm{pmol}$ \\
\hline & Loop B & CCGCGGCCTATCAGC & 16S rRNA & 40 pmol \\
\hline \multirow[t]{6}{*}{ III } & $\mathrm{F} 3$ & CTGGCTCAGGACGAACG & 16S rRNA & $5 \mathrm{pmol}$ \\
\hline & B3 & GCTCATCCCACACCGC & 16S rRNA & $5 \mathrm{pmol}$ \\
\hline & FIP & CACCCACGTGTTACTCATGCCAAGTCGAACGGAAAGGTCT & 16S rRNA & $30 \mathrm{pmol}$ \\
\hline & BIP & TCGGGATAAGCCTGGACCACAAGACATGCATCCCGT & 16S rRNA & $30 \mathrm{pmol}$ \\
\hline & Loop F & GTTCGCCAC TCGAGTATCTCCG & 16S rRNA & $20 \mathrm{pmol}$ \\
\hline & Loop B & GAAACTGGGTCTAATACCGG & 16S rRNA & 20 pmol \\
\hline \multirow[t]{4}{*}{ IV } & F3 & CTAAGGGGCCTTTTGACGG & $\operatorname{rim} \mathrm{M}$ & $5 \mathrm{pmol}$ \\
\hline & B3 & CACCACTTCGGTGACGA CAC & $\operatorname{rim} \mathrm{M}$ & 5 pmol \\
\hline & FIP & TCCAGCGAGTCGCACCAACAGTTTGGCAGTGCGGTGAGTTACGTC & $\operatorname{rim} \mathrm{M}$ & 20 pmol \\
\hline & BIP & GACGCCGATGACTTGCCCCCTTTTTCGCCGTCTGGACCATAAGC & $\operatorname{rim} \mathrm{M}$ & $20 \mathrm{pmol}$ \\
\hline
\end{tabular}

The primers are published previously by I (Iwamoto et al, 2003), II (Yamaguchi et al, 2006), III (Pandey et al, 2008), and IV (Zhu et al, 2009). 
polymerase large fragment (New England Biolabs) and $2.0 \mu \mathrm{L}$ of template DNA. The mixture was incubated and heated at the temperature specific for particular primer set being used in the LAMP real-time turbidimeter (LA-320C; Teramecs).

\section{Specificity of LAMP primers sets for rapid detection of Mtb assays}

The specificity of "three sets" of LAMP primers sets, i.e. set primers $I^{5}, I^{6}$ and $\boldsymbol{I I I}^{14}$ were tested using 12 Mycobacteria species : M. tuberculosis H37Rv (ATCC25618), M. avium (JATA51-01), M. intracellulare (JATA52-01), M. kansasii (JATA21-01), M. fortuitum (JATA61-01), M. gordonae (JATA33-01), M. terrae (JATA46-01), M. szulgai (JATA32-01), M. abscessus (JATA63-01), M. marinum (JATA22-01), M. lentiflavum (JATA9N-01), M. celatum (JATA9L-01).

\section{Sensitivity of several instruments for LAMP method}

To develop the application of LAMP method in the limited sources area, different simple equipments for nucleic acid amplification and detection system were investigated. The amplification equipments tested were LAMP real-time turbidimeter (LA-320C, Teramecs), heating block, and water bath. For detection system, fluoresence or precipitation method were tested. All tests used Loopamp DNA Amplification kit (Eiken Chemical Co Ltd.) with set primers I and 2.0- $\mu$ L DNA's of $M t b \mathrm{H} 37 \mathrm{Rv}$ (DNA extract A) as template. ${ }^{5,14}$

\section{Evaluation of MTB-LAMP against Indonesian TB samples}

A number of 122 DNA's $M t b$ were, chosen from the 437 archived AFB positive sputum from Indonesian TB Patients by randomized systematic sampling (RSS). After decontamination by $\mathrm{N}$-acetylcysteine- $\mathrm{NaOH}$ and subsequent concentration by centrifugation, ${ }^{2}$ samples were split prior to processing: a $200 \mu \mathrm{L}$ aliquot from each sample was prepared for LAMP testing and the remaining for culture growth. The DNA was extracted from specimens using DNeasy Blood and tissues kit (QIAamp Diagnostics Qiagen) and was stored at $-70^{\circ} \mathrm{C}$ before used. For culture growth, $100 \mu \mathrm{L}$ sputum suspension was inoculated into two culture tubes containing Lowenstein Jensen media (Becton Dickinson, Spark, MD) and incubated at $37^{\circ} \mathrm{C}$. Cultures were observed up to 8 weeks for any colony growth.

\section{Amplification reaction}

LAMP reaction was performed using Loopamp DNA-amplification kit $2.0 \mu \mathrm{L}$ archieved samples of DNA lysate and water bath as nucleic acid amplification instrument. ${ }^{5}$ Results were visualized with fluorescence detection reagent (EIKEN) according to the manufacturer's instructions by UVlamp. The confirmation test for any discrepancy between LAMP and LJ results or both LAMP and LJ gave negative result, was performed by PCR and DNA sequencing.

\section{PCR reaction}

PCR test were carried out under the standard protocol for DNA amplification works in BSL-2 laboratory. The PCR mix $(20 \mu \mathrm{L})$ contained $12.5 \mu \mathrm{L} 2 \mathrm{x}$ Rx mix [40 mM Tris- $\mathrm{HCl}$ (pH 8.8), $20 \mathrm{mM} \mathrm{KCl,} 16 \mathrm{mM}$ $\mathrm{MgSO}_{4}, 20 \mathrm{mM}(\mathrm{NH} 4)_{2} \mathrm{SO}_{4}, 0.2 \%$ Tween 20, $1.6 \mathrm{M}$ Betaine, $2.8 \mathrm{mM}$ dNTPs], $1.0 \mu \mathrm{L}$ of Platinum ${ }^{\circledR}$ Taq DNA polymerase (Invitrogen Inc.), $0.5 \mu \mathrm{L}$ for each primers ( $\mathrm{F} \& \mathrm{R}$ primer), $5.5 \mu \mathrm{L}$ water and add with $5.0 \mu \mathrm{L}$ of lysate DNA. The primers were designed by Primer3 software based on gyrB Mtb H37Rv gene database obtained from the National Center for Biotechnology Information (NCBI) with Forward and Reverse Primer (NIHRD Patent). The reactions were incubated in a programmable heating block (Biorad Diagnostic System Instrument) at $96^{\circ} \mathrm{C}$ for $2 \mathrm{~min}$ as an initial pre-denaturation step and then subjected to 30 cycles consisting of $1 \mathrm{~min}$ at $96^{\circ} \mathrm{C}$, $30 \mathrm{~s}$ at $87^{\circ} \mathrm{C}$ followed by terminal elongation for 2 min at $72^{\circ} \mathrm{C}$ and hold in $4^{\circ} \mathrm{C}$ before started the new cycle. The PCR products were electrophoresed in a $2 \%$ TAE agarose gel and $10 \mu \mathrm{L}$ blue juice gel loading reagent (Invitrogen Inc.) were used for detection by using Gel.Doc-XR (Biorad Diagnostic System Instrument).

\section{Sequencing reaction}

The PCR mix $(10 \mu \mathrm{L})$ contained $4 \mu \mathrm{L}$ of buffer sequencing and $2 \mu \mathrm{L}$ of BDDT v3.1 (Applied Biosystem Japan Ltd.), $2 \mu \mathrm{L} g y r B \mathrm{~F}$ or $\mathrm{R}$ primer (NIHRD patent), $2.0-\mu \mathrm{L}$ nuclease free water were added to $2 \mu \mathrm{L}$ DNA of lysate. The sequencing reaction consisted of incubation at $96^{\circ} \mathrm{C}$ for $1 \mathrm{~min}$ as an initial pre-denaturation step, then 30 cycles of denaturation and annealing, $10 \mathrm{~s}$ at $96^{\circ} \mathrm{C}$ and $5 \mathrm{~s}$ at $55^{\circ} \mathrm{C}$, and stage of terminal elongation for $4 \mathrm{~min}$ at $60^{\circ} \mathrm{C}$ and hold at $4^{\circ} \mathrm{C}$. The isolate was purified by addition of $60 \mu \mathrm{L} \mathrm{70 \%} \mathrm{isopropanol} \mathrm{followed} \mathrm{by} \mathrm{incubation} \mathrm{at}$ $2-8^{\circ} \mathrm{C}$ for $15 \mathrm{~min}$. The supernatant was removed after centrifugation and $60 \mu \mathrm{L} 70 \%$ ethanol was added to the pellet, spinned down for $15 \mathrm{~min}$. After removal of the supernatant, the pellet was dried at room temperature for $60 \mathrm{~min}$ and $10 \mu \mathrm{L} \mathrm{Hi}$-Di formamide was added then loaded on 3130xl-Genetic Analyzer (Applied Biosystems Diagnostic Instrument). 


\section{RESULTS}

Comparison between two commercial DNA extraction kits (Qiagen and Amplicor) on Loopamp DNA amplification kit (Eiken Chemical Co Ltd.) using set primers III specific for $16 \mathrm{~S}$ rRNA showed that LAMP could amplify 1-10 copies of bacterial cells DNA extracted by Amplicor kit while with Qiagen required a minimum of $10^{3}-10^{4}$ copies bacterial cells (Figure 1 ).

Sensitivity of "four sets" LAMP primers to identify Mtb H37Rv DNAs diluted in serial showed that $10 \mathrm{fg}$ to $1.0 \mathrm{pg}$ gDNA from 10 -fold serially diluted DNA of Mtb H37Rv were only detected by sets primers specific for $16 \mathrm{~S}$ rRNA and gyrB genes. The fastest amplification began after $11 \mathrm{~min}$ incubation by set primers III, followed by set primers II after $25.48 \mathrm{~min}$ incubation and the last amplification showed by set primers I after $26.36 \mathrm{~min}$ of incubation (Table 2).

The specificity of the sets of LAMP primers were evaluated against 11 species of Mycobacteria other than tuberculosis (MOTT) and Mtb H37Rv strain which were the collection of the Medical Faculty, Kobe University. A set primers specific for Mycobacterium genus was also used as a positive control. Using sets primers I-III, Mtb H37Rv strain was amplified after $9-18$ minutes incubation. The specificity of those sets primers were summarized by comparing amounts of Mycobacteria amplified by each set primers at one circle of reaction (Table 3 ). The results also showed that the most promising set primers with highest specificity was set primers I.

Comparison of simple equipments for LAMP reaction, i.e. were water bath, heating block and LAMP real time turbidimeter (LA-320C, Teramecs) used set primers I for gyr B gene (Table 2 and 3 ) showed that no sensitivity difference among the three instruments and all gave clear results. Precipitation occurred in the positive tube detected by the LAMP real time turbidimeter instrument and the fluorescence could also be observed in the positive samples amplified in the water bath and heating block instrument. The glow was showed up by

\section{A}

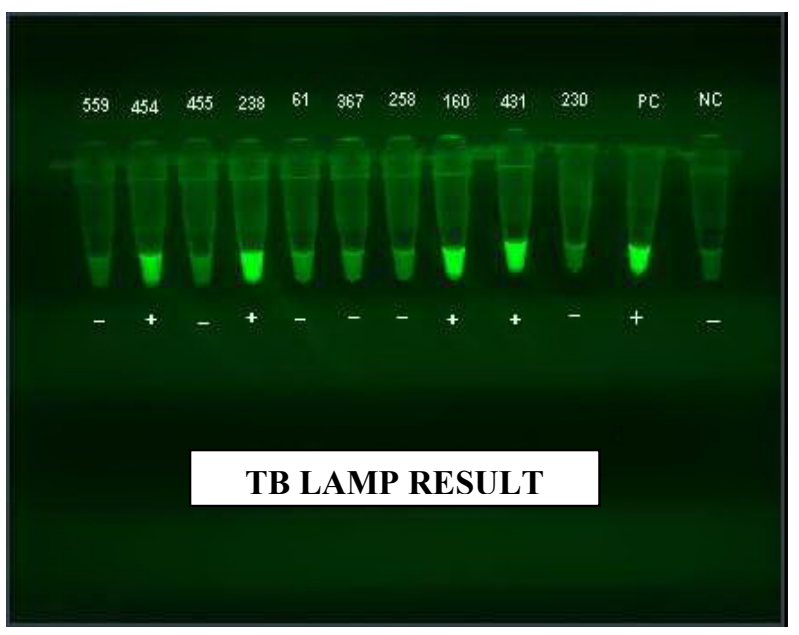

B

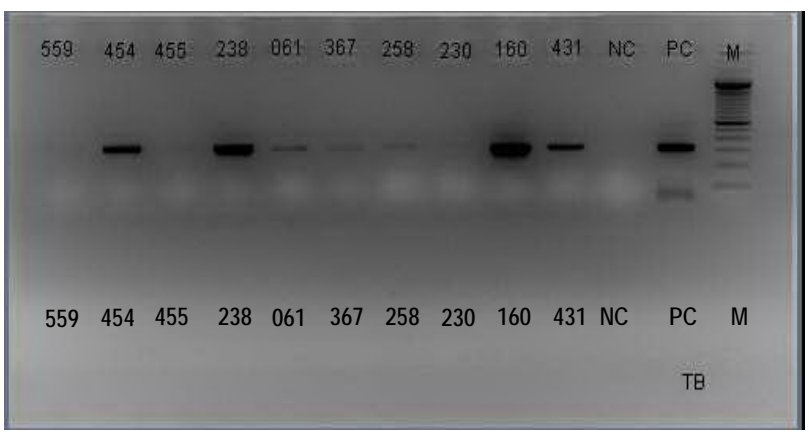

Figure 1. A. Visual detection of gyrB LAMP reaction using fluorescent indicator and water bath equipment under $U V$ light. Tube no.1 - Tube no.10: [DNA] isolates; Tube no.11: [100] PFU Mtb H37Rv; Tube no.12: DW (negative control). B. Agarose gel electrophoresis results for gyrB LAMP reaction of DNA isolates (lane 1 - 10) and positive control and $M, 100 \mathrm{bp}$ marker

Table 2. Sensitivity of four set of Mtb LAMP primers using Loopamp DNA Amplification kit

\begin{tabular}{lccccccccc}
\hline & \multicolumn{7}{c}{ Primers } & \multicolumn{7}{c}{ Dilution of purified DNA concentration Mtb. H37Rv } \\
\cline { 2 - 7 } & $10 \mathrm{ng}$ & $1 \mathrm{ng}$ & $100 \mathrm{pg}$ & $10 \mathrm{Pg}$ & $1 \mathrm{Pg}$ & $100 \mathrm{Fg}$ & $10 \mathrm{Fg}$ & $1 \mathrm{Fg}$ \\
\hline IWAMOTO - M.tb. & + & + & + & + & + & & \\
YAMAGUCHI - M.tb & + & + & + & + & + & + & & \\
PANDEY - M.tb. & + & + & + & + & + & + & + & \\
ZHU - Mtb. & - & - & - & - & - & - & - & - \\
IWAMOTO - M.univ. & + & + & + & + & + & + & & \\
\hline
\end{tabular}

The assays were done using LAMP real time turbidimeter (LA-320C, Teramecs) 
Table 3. Specificity of LAMP primers sets using loopamp kit EIKEN for identified 12 strain of Mycobacteria sp

\begin{tabular}{lccccc}
\hline \multicolumn{1}{c}{ Sample } & Origin & $\begin{array}{c}\text { Iwamoto } \\
\text { Mtb. Primer }\end{array}$ & $\begin{array}{c}\text { Yamaguchi } \\
\text { Mtb. primer }\end{array}$ & $\begin{array}{c}\text { Pandey } \\
\text { Mtb. primer }\end{array}$ & $\begin{array}{c}\text { Iwamoto } \\
\text { M.univ. primer }\end{array}$ \\
\hline Mtb.H37Rv & ATCC25618 & + & + & + & + \\
$M$. avium & JATA51-01 & - & + & - & + \\
$M$. intracellulare & JATA52-01 & - & + & - & + \\
$M$. kansasii & JATA21-01 & - & - & + & + \\
$M$. fortuitum & JATA61-01 & - & - & - & + \\
$M$. gordonae & JATA33-01 & - & - & - & + \\
$M$. terrae & JATA46-01 & - & + & + & + \\
$M$. szulgai & JATA32-01 & - & + & - & + \\
$M$. absescuss & JATA63-01 & - & - & - & + \\
M. marinum & JATA22-01 & - & + & + & + \\
M. lentiflavum & JATA9N-01 & - & + & + & + \\
M. celatum & JATA9L-01 & - & + & + & + \\
\hline
\end{tabular}

The assays were done using LAMP real time turbidimeter (LA-320C, Teramecs)

Table 4. Sensitivity of the different LAMP instruments for rapid detection of Mtb

\begin{tabular}{|c|c|c|c|c|c|c|c|}
\hline \multirow[b]{2}{*}{ Assay } & \multicolumn{5}{|c|}{ Sample } & \multirow{2}{*}{$\begin{array}{c}\text { Control }+ \\
\text { DNA } \\
\text { H37Rv } \\
10 \\
\text { ug/ul } \\
\end{array}$} & \multirow{2}{*}{$\begin{array}{l}\text { Control - } \\
\text { DW }\end{array}$} \\
\hline & $\begin{array}{c}\text { DNA } \\
\text { H37Rv } \\
10^{5} \\
\text { Cells }\end{array}$ & $\begin{array}{c}\text { DNA } \\
\text { H37Rv } \\
10^{4} \\
\text { cells }\end{array}$ & $\begin{array}{c}\text { DNA } \\
\text { H37Rv } \\
10^{3} \\
\text { Cells }\end{array}$ & $\begin{array}{c}\text { DNA } \\
\text { H37Rv } \\
10^{2} \\
\text { cells }\end{array}$ & $\begin{array}{c}\text { DNA } \\
\text { H37Rv } \\
10^{1} \\
\text { Cells }\end{array}$ & & \\
\hline $\begin{array}{l}\text { LAMP } \\
\text { Machine }\end{array}$ & + & + & + & + & + & + & $\cdot$ \\
\hline $\begin{array}{l}\text { Water } \\
\text { Bath }\end{array}$ & + & + & + & + & + & + & - \\
\hline $\begin{array}{l}\text { Heating Block/ } \\
\text { Thermo Cycler }\end{array}$ & + & + & + & + & + & + & \\
\hline
\end{tabular}

addition fluorescence detection reagent (EIKEN) in the last two serial dilutions according to the manufacturer's instructions (Figure 1A).

Analysis of the LAMP method on 122 samples TB patients showed that 114 isolates gave positive LAMP signals included 14 positive tests originated from negative LJ cultures. There were 8 isolates gave negative LAMP signals and three out the eight were from positive LJ cultures and five from negative LJ cultures (Figure 1A).

PCR tests were conducted using primers specific on gyr B gene, which had been designed by Primer3 software (NIHRD patent). The PCR products with positive electrophoresis band were further sequenced, and were compared to gyr B sequence of Mtb H37Rv reference genome using BLAST (Basic Local Alignment Search Tool) (http://www.ncbi.nih. gov/blast).
Table 5. Sensitivity of MTB-LAMP test by water bath instrument using gyrB primers set (Iwamoto et al) for one hundred twenty two of Indonesian TB sputum isolates

\begin{tabular}{lcc}
\hline & $\begin{array}{c}\text { LJ Cultures } \\
\text { or } \\
\text { PCR }(+)\end{array}$ & $\begin{array}{c}\text { LJ Cultures } \\
\& \\
\text { PCR }(-)\end{array}$ \\
\hline $\begin{array}{l}\text { LAMP } \\
\text { Test }(+)\end{array}$ & 114 & - \\
LAMP & & \\
Test $(-)$ & 7 & 1 \\
\hline
\end{tabular}

All fourteen isolates with LAMP positive results and negative LJ cultures showed strong to medium signals in electrophoreses gel (Figure 1B). Four isolates of five isolates from LAMP negative results and negative LJ cultures showed low signals at electrophoreses gel (Figure 1B), indicated low concentration of the DNA. The last sample showed no signals neither in PCR, i.e. 
isolates no. 455. Three other isolates with negative LAMP test and positive LJ culture (isolates no.061, 367 and 258) showed positive band in electrophoreses gel with medium signals (Figure 1B). The BLAST analysis of all isolates with discrepant results and PCR positive showed around $97-100 \%$ similarity to gyr B sequence of $M t b \mathrm{H} 37 \mathrm{Rv}$ reference genome and indicated that those DNA sequences were DNA of $M t b$. The results of LAMP-TB test in the detection of $M t b$ in sputum specimes after confirmation using PCR and sequencing can be seen in table 5 .

\section{DISCUSSION}

The DNA extraction and amplification kits play an important role to establish LAMP reaction for identification TB. The reaction depends on the amounts of bacterial DNA that had been extracted to be amplified. In this study, DNA obtained from both commercialized extraction kits (Qiagen and Amplicor) gave similar sensitivity of loopamp DNA amplification. However, since we expected this LAMP method could be applied in limited-source laboratories, we still need to search and analyse simpler standardized protocols for DNA isolation. Furthermore, this method involves pipetting of very small volume, thus, it is important to maintain the skill and consistence of technicians to keep the procedures free from contamination and failure.

LAMP reaction also depends on sensitivity of set primers which had been used. The sets primers specific on gyrB gene and $16 S$ rRNA gene had six primers each which can be recognize eight distinct regions in the specific gene of $M t b$ genome..$^{5,14,16}$ The set primers were composed of outer F3 and B3 primers, inner FIP and BIP primers, and FLP and BLP loop primers to shorten the time of amplification reaction. Other published set primers, which specific on $\operatorname{rim} \mathrm{M}$ gene, had only four primers to recognize six distinct regions in the gene of $M t b$ genome. ${ }^{15}$ The primers were composed of outer F3 and B3 primers and inner FIP and BIP primers, without using FLP and BLP loop primers. In this study, the results indicated that set primers targeting on $\operatorname{rim} \mathrm{M}$ gene did not yield any amplification until 60 minutes incubation, while other sets primers specific on $16 \mathrm{~S}$ rRNA gene (Pandey) were the most sensitive primers with faster amplification (11 min after incubation) and $10 \mathrm{fg}$ DNA were detected. Previous literatures had written that LAMP reaction time can be even less than half of that for the original LAMP method by using loop primers, ${ }^{3}$ so the lack of amplification using set primers specific on rim $\mathrm{M}$ gene might be caused by lack of FLP and BLP primers.
Our results on the specificity of sets primers were showed that one of the set primers which spesific on $16 \mathrm{~S}$ rRNA gene published previously by Yamaguchi, and Pandey could recognized 7 and 6 species others than $M t b$ (Table 3) respectively. This can be explained because $16 \mathrm{~S}$ rRNA gene is a common gene which presents in all species of Mycobacteria, the known and novel Mycobacteria. ${ }^{17}$ Meanwhile the set primers specific on gyrB gene showed higher specificity only detected $M$. tuberculosis. Conserved sequence of the gene may lead the set primers designed on gyr B gene become the most suitable primers for detected $M t b$ in samples. ${ }^{18}$

LAMP method using LAMP turbidity instrument for detection of TB cases and other mycobacterial diseases have come into common use in industrialized countries because of their great advantage in speed (sensitivity and specificity) compared to culture. The complexity and insufficient budget to support for a precision instrument and high degree of technical support make them unsuitable for most developing country settings. Applied LAMP method using common incubator like water bath or heating block can give an opportunity to improve rapid diagnosis of TB in limited sources area. The results of the sensitivity evaluation test for LAMPTB assays using three different instruments showed that using simple incubator like water bath and heating block is comparable to turbidity instrument and it could detect M.tuberculosis H37Rv at 10 bacterial cells. This alternative instrument can make the application of LAMP method in developing countries more applicable.

Analysis of MTB-LAMP assay against DNA's MTB archieved samples aimed to determine the feasibility and reliability of LAMP method in laboratories with limited facilities, using simple incubator and visual readout by UV fluorescence and naked eyes. It showed that the amount of time for DNA extraction very much depended on the skill of the workers; two hours for 30 clinical isolates on average. The risk of DNA contamination has to be taken into account as a weakness of the test, unless strict rules to prevent contamination are observed. Assessment on the sensitivity of LAMP method compared to culture growth with PCR as the confirmation test showed $94.2 \%$ (114/121) positivity rate, included the 14 samples negative on LJ culture, suggesting LAMP method is better to detect $M t b$ than culture or PCR. In conclusion, this MTB-LAMP could be use in the area with limited sources. However, there was still $3.6 \%$ false negative results when tested on TB samples from Indonesia; this could be due to variability of DNA sequence recognized by the primers used; thus development of new set of LAMP-TB primer which 
can be constructed from conserved sequence of $M t b$ circulated in Indonesia is still a need.

\section{Acknowledgments}

We gratefully thank to Director General of NIHRD - Indonesian $\mathrm{MoH}$ for his support and guidance. We are also thankful to Director and staff of the Hyogo Perfectural Institute of Public Health and Consumer Science, Public Health Science Research Center for providing the laboratory facility. We would also like to thank the Dean and all staff at Department of Microbiology, Kobe University Graduate School of Medicine for their technical support. This work was supported in part by DIPA 2009 and DIPA 2010 at National Institute of Health Research and Development, Indonesia Ministry of Health.

\section{REFERENCES}

1. World Health Organization. New technologies for tuberculosis control: a framework for their adoption, introduction and implementation. France: WHO Library Cataloguing-in-Publication Data; 2007.

2. Forbes BA, Sahm DF, Weissfeld AS. Bailey \& Scott's diagnostic microbiology. 12th ed. Philadelphia: Mosby Elsevier; 2007. p. 509-478.

3. Notomi T, Okayama H, Masubuchi H, Yonekawa $\mathrm{T}$, Watanabe K, Amino N, et al. Loop-mediated isothermal amplification of DNA. Nucleic Acids Res. 2000;28:e63.

4. Nagamine K, Watanabe K, Ohtsuka K, Hase T, Notomi T. Loop-mediated isothermal amplification reaction using a nondenatured template. Clin Chem. 2001;47(9):1742-3.

5. Iwamoto T, Sonobe T, Hayashi K. Loop-mediated isothermal amplification for direct detection of Mycobacterium tuberculosis complex, $M$. avium, and $M$. intracellulare in sputum samples. J Clin Microbiol. 2003;41:2616-22.

6. Kuboki N, Inoue N, Sakurai T, Di Cello F, Grab DJ, Suzuki H, et al. Loop-mediated isothermal amplification for detection African trypanosomes. J Clin Microbiol. 2003;41:5517-24.

7. Hong TC, Mai QL, Cuong DV, Parida M, Minekawa H, Notomi T, et al. Development and evaluation of a novel loop-mediated isothermal amplification method for rapid detection of severe acute respiratory syndrome coronavirus. J Clin Microbiol. 2004;42:1956-61.

8. Hase, T. Rapid detection of Mycobacterium tuberculosis complex from sputum samples using novel loop-mediated isothermal amplification. EIKEN Chemical Co., LTD; 2007.

9. Ihira M, Yoshikawa T, Enomoto Y, Akimoto S, Ohashi $\mathrm{M}$, Suga S, et al. Rapid diagnosis of human herpesvirus 6 infection by a novel DNA amplification method, loopmediated isothermal amplification. J Clin Microbiol. 2004;42(1):140-5.

10. EIKEN Genome Site [Internet]. 2007 [cited 2009 Nov]. Available from: http://loopamp.eiken.co.jp/e/lamp/index. html. 2009/11/25.

11. Boehme CC, Nabeta P, Henostroza G, Raqib R, Rahim Z, Gerhardt M, et al. Operational feasibility of using loopmediated isothermal amplificatin for diagnosis of pulmonary tuberculosis in microscopy centers of developing countries. J Clin Microbiol. 2007;45:1936-40.

12. Parida M, Posadas G, Inoue S, Hasebe F, Morita K. Realtime reverse transcription loop-mediated isothermal amplification for rapid detection of West Nile virus. J Clin Microbiol. 2004;42:257-63.

13. Conville PS, Witebsky FG. Analysis of multiple differing copies of the 16S rRNA gene in five clinical isolates and three type strains of Nocardia species and implications for species assignment. J Clin Microbiol. 2007;45:1146-51.

14. Pandey BD, Poudel A, Yoda T, Tamaru A, Oda N, Fukushima Y, et al. Development of an in-house loop-mediated isothermal amplification (LAMP) assay for detection of Mycobacterium tuberculosis and evaluation in sputum samples of Nepalese patients. J Med Microbiol. 2008;57:439-43.

15. Zhu RY, Zhang KX, Zhao MQ, Liu YH, Xu YY, Ju CM, et al. Use of visual loop-mediated isothermal amplification of rimM sequence for rapid detection of Mycobacterium tuberculosis and Mycobacterium bovis. J Microbiol Methods. 2009;78:339-43.

16. Yamaguchi, et al. in Japanese alphabeth. 2006. [cited 2009 Dec]. Available from: http://www.j-tokyo.com/2006/C12N/ JP2006-061134.shtml. Japanese.

17. Wu X, Zhang J, Liang J, Lu Y, Li H, Li C, et al. Comparison of three methods for rapid identification of mycobacterial clinical isolates to the species level. J Clin Microbiol. 2007;45(6):1898-903.

18. Chimara E, Ferrazoli L, Leão SC. Mycobacterium tuberculosis complex differentiation using gyr B restriction fragment length polymorphism analysis. Mem Inst Oswaldo Cruz, Rio de Janeiro. 2004;99(7):745-8. 